Schwartz, Agatha. "Csobánka, Zsuzsa. 2013: Majdnem Auschwitz ('Almost Auschwitz'). Budapest: Kalligram. 279 pp." Hungarian Cultural Studies. e-Journal of the American Hungarian Educators Association, Volume 8 (2015): http://ahea.pitt.edu DOI: 10.5195/ahea.2015.201

\title{
Csobánka, Zsuzsa. 2013: Majdnem Auschwitz ('Almost Auschwitz'). Budapest: Kalligram. 279 pp.
}

\section{Reviewed by Agatha Schwartz, University of Ottawa, Canada}

Until recently, Zsuzsa Csobánka (b. 1983) has been publishing mainly poetry, short stories and literary criticism. It was only in 2011, following her first volume of poetry Bog ('Knot,' 2009) that she published her first novel, Belém az ujját ('His Finger Into Me'), to be followed by another volume of poetry in the same year, Hideg bünök ('Cold Sins'), and two novels in 2013: Elveszíteni egy férfit ('Losing a Man') and Majdnem Auschwitz ('Almost Auschwitz'). Critics have called the latter a survivors' novel, one that examines the impact of the Holocaust and trauma on the generations of the survivors' children and grandchildren.

The main narrator in the novel, János, is the grandson of Holocaust survivors Jákob and Edit Zinger. Jákob returned from Auschwitz to his family in Budapest; his wife Edit was sodomized by a young Hungarian Arrow Cross militia man while pregnant with their son Janek, and subsequently survived the mass shooting of Budapest Jews on the banks of the Danube. It is this grandson János who, as an adult at the beginning of the novel, starts to search for an answer to the question why his grandfather Jákob, originally from Cracow, left Edit and Janek after he had been reunited with them in Budapest. The novel then becomes a travel through space and time, with flashes into the past and back into the present. Csobánka divides her novel into seven chapters, each named after a different geographical location mainly in Central Europe but also beyond: Budapest, Cairo, Kathmandu, Auschwitz, Cracow, Palagruža (a Croatian archipelago situated in the middle of the Adriatic Sea), and Szabadka (Subotica in Serbian; formerly part of Hungary, presently a city with a large Hungarian population in the Vojvodina county of northern Serbia).The author's previous experience as a poet and short fiction writer shows in the way she divides her chapters into small sections with each carrying a title that could well be the title of a poem, such as "Vízazúr" ('Water Azure'); "Kék” ('Blue'); or “Női kezek” ('Hands of a Woman'), to name but a few.

Although the effects of the trauma of the Holocaust on the survivors, their children and grandchildren is the main axis around which the novel's plot is built, Csobánka adds to it another traumatic experience for many Hungarians, namely, the 1950s Communist dictatorship. Both traumas have left their traces in the narrator's family, as his maternal aunt Éva, who lived in Vienna, was accused, during a visit to Budapest, of being a "facsist whore" and was subsequently imprisoned, raped and tortured in Hungary. It thus comes as no surprise that the narrator's father gives him the advice to remain a coward, to which János adds his comment: "but these words were almost wasted on me since I had sucked in fear with my mother's milk" ('anyatejjel szívtam magamba a félelmet,' 23). The legacy of terror and trauma for the narrator is a good example of what Marianne Hirsch has termed "postmemory," meaning a fragmented memory of traumatic events that happened in the past, sometimes even before the affected person was born (Marianne Hirsch, The Generation of Postmemory - Writing and Visual Culture After the Holocaust. New York: Columbia UP, 2012).

(cc) Br

ULIS D-Serle 
Schwartz, Agatha. "Csobánka, Zsuzsa. 2013: Majdnem Auschwitz ('Almost Auschwitz'). Budapest: Kalligram. 279 pp." Hungarian Cultural Studies. e-Journal of the American Hungarian Educators Association, Volume 8 (2015): http://ahea.pitt.edu DOI: 10.5195/ahea.2015.201

Although these memories continue to impact the present, it remains difficult to put them into a cohesive narrative and to understand them. This difficulty helps to explain what the reader of Csobánka's novel may at times experience as a frustrating abundance of details and ambiguities, lack of cohesion, side plot lines that are broken off, or characters that seem to pop out of nowhere only to quickly disappear again and never to return. This fragmentation can, however, be interpreted as intentional on the part of the author so as to reflect the effect of trauma on the survivors and their offspring. While Csobánka explores how the postgeneration comes to terms with their mental imprint and patterns of behavior as a result of inherited trauma, she also demonstrates the embodiment of trauma by those immediately affected by it. Trauma is literally inscribed on their bodies as exemplified by numerous statements and metaphors in the novel, the most powerful of them being, probably, the one about the body's memory of suffering: "The tissues carry the memories of the past, the camp and the Danube, the barracks and the Free Port [Szabadkikötö]" (99).

The novel, however, seeks to go beyond the traumatic experiences and their after-effects. It thus explores what Hirsch calls "postmemorial work," i.e. the attempt to work through the inherited trauma via aesthetic experience. The narrator's search for the history of his grandparents at various geographic locations is motivated by his desire to leave his fears behind. The use of a rich array of poetic imagery constitutes one aspect of the aesthetic working-through. One example of this is the way in which the narrative weaves in the imagery of water by recurrent allusions to rivers, lakes, sea and rain while joining these to various states and acts of life, such as love, death and cleansing. Connected to water imagery and symbolism are bridges that both unite and separate between characters and experiences, as many important encounters and emotional epiphanies in the novel happen on or around bridges.

Adding further building blocks to the "postmemorial work," the novel increasingly turns into an exploration of love and betrayal, centered around the love story of Jákob and Edit but relating also to other couple relations along the way, including that of the narrator and his wife. The commonplace that love brings fulfilment as well as hurts receives a complex investigation through rather graphic yet poetic descriptions of sexual intimacy (that are a welcome balance to the equally graphic but brutal descriptions of sexual violence and trauma inflicted upon women in this novel). The attempts and failures of various characters to remain close to each other, true to themselves and to their loved one(s), and form lasting relationships often result in their ultimate realization of the impossibility to fulfil love's demands and promises against the forces of external and inner destruction that continue to haunt them all ever after Auschwitz. This central theme of love, however, also constitutes a weakness in the novel's composition, as the experiences of the Holocaust seem to remain rather in the background regarding Jákob's inability to re-build his life with his family, and his ultimate escape from Edit seems to result mainly from his inability to focus his sexual desire solely on his wife.

Csobánka addresses the question of the limits of language, of what it can express and where and when it is bound to succumb to silence or become synonymous with the pain of trauma. The narrator's aunt Éva leaves behind her Hungarian mother tongue following her abusive treatment in the Hungarian prison. Edit curses her Hungarian mother tongue because it cannot help her grasp the emptiness that Jákob's departure left behind, and János relies on English rather than on Hungarian to guide him through the sites of Auschwitz (by then a museum and memorial site), where his grandfather was once interned. 
Schwartz, Agatha. "Csobánka, Zsuzsa. 2013: Majdnem Auschwitz ('Almost Auschwitz'). Budapest: Kalligram. 279 pp." Hungarian Cultural Studies. e-Journal of the American Hungarian Educators Association, Volume 8 (2015):

http://ahea.pitt.edu DOI: 10.5195/ahea.2015.201

In spite of Csobánka's focus of a male narrator, I would still qualify this novel as woman's prose, as comes through in the descriptions of the female body and its sexuality, the gender-specific suffering and traumas endured by female characters within the broader historical context of World War II and the Holocaust, as within that of Communism and beyond. All these, as depicted in Majdnem Auschwitz, could have only come from a woman's experiences and sensibility. These dscriptions and other complexities make Csobánka's novel a beautiful and challenging read at one and the same time. 